\title{
Effect of Zero Tillage and Analysing the Performance of Six Different Cultivars of Wheat (Triticum aestivum L.)
}

\author{
Mamta $^{1}$, Mizanul Haque ${ }^{1 *}$, Nitu Kumari ${ }^{2}$, Manish Kumar ${ }^{3}$, \\ Ashwini Kumar ${ }^{4}$ and Pooja Kumari ${ }^{4}$
}

\author{
${ }^{1}$ Department of Agronomy, Bihar Agricultural College, Sabour, Bihar, India \\ ${ }^{2}$ Department of Horticulture, V.K.S. College of Agriculture, Dumraon, Buxar, India \\ ${ }^{3}$ Department of Entomology, Bihar Agricultural College, Sabour, Bihar, India \\ ${ }^{4}$ Department of Horticulture (Fruit \& Fruit Tech.), \\ Bihar Agricultural College, Sabour, Bihar, India
}

*Corresponding author

\begin{tabular}{|l|}
\hline Ke y w or d s \\
$\begin{array}{l}\text { Conventional tillage } \\
\text { (CT), Zero tillage } \\
\text { (ZT), Genotypes }\end{array}$ \\
\hline Article Info \\
\hline $\begin{array}{l}\text { Accepted: } \\
\text { 26 May 2020 } \\
\text { Available Online: } \\
\text { 10 June 2020 }\end{array}$ \\
\hline
\end{tabular}

A B S T R A C T

Sowing of wheat in left optimum moisture through zero tillage technology not only provides a good germination but also improves the soil fertility, soil physical properties and saves time hence increases net return on sustained basis. It causes minimal disturbance of soil structure and texture ultimately increases size of soil aggregates. In the present experimental study, genotypes and tillage effect was observed. The investigation was done with six different genotypes and two different tillage operation. Zero-tillage decreases the cost of production and saves time for sowing of wheat as compared to conventional tillage. Content of NPK in grains under zero tillage was N (1.44\%), P $(0.46 \%)$, and $\mathrm{K}(0.28 \%)$, while that of conventional tillage NPK content in grains was N $(1.44 \%), \mathrm{P}$ $(0.45 \%)$, and $\mathrm{K}(0.28 \%)$. The minimum tillage and direct drilling system is energy and cost saving and environmental friendly reducing the soil pollution as compared to conventional tillage practices. In case of conventional tillage system thermal conductivity, bulk density and compaction of soil increases due to use of heavy agricultural machinery which reduces infiltration rate, soil porosity and plant growth. Among the six various cultivars (BRW 3708, CBW 38, DBW 39, HD 2967, HD 2733, $\mathrm{K}$ 0307), the best result was observed in BRW 3708 in terms of nutrient uptake in grains $(\mathrm{kg} / \mathrm{ha})$ as well as in nutrient uptake in straw ( $\mathrm{kg} / \mathrm{ha}$ ). Zero tillage is superior over conventional tillage because higher yield were recorded on zero tillage farms than that of conventional tillage wheat farms in addition to its edge of eco-friendly practice.

\section{Introduction}

Wheat (Triticum aestivum L.) is an important staple food of millions of people and also winter cereal crop that plays an important role in national food security of India. Cultivation of wheat has played a dramatic role in accelerating green revolution which made
India largely self sufficient in food grain production. India is the second largest producer of wheat in the world with average annual production of more than $98 \mathrm{mt}$ (201617).

Bihar is an important wheat growing state in the country and produces about $5.3 \mathrm{mt}$ of 
wheat from 2.3 mha of area with productivity of $26 \mathrm{q} / \mathrm{ha}$, which quite low as compared to national average productivity (31 q/ha). The eastern region of the Indo-Gangetic plains of south Asia, which comprises Bihar, is considered relatively favourable for wheat production. Many farmers grow late maturing varieties of rice, causing late sowing of wheat. The delay of every successive day in sowing beyond middle of November decreases the grain yield progressively (Ali et al., 2010; Irfaq et al., 2005 \& Sharma, 1992). Therefore, to avoid delay in planting and reduce the cost of production, farmers have started adopting resource conserving technologies such as zero tillage in wheat production (Gupta and Seth, 2007).

Saving in inputs cost, fuel consumption and irrigation water use have reported due to adoption of zero tillage in wheat cultivation (Malik et al., 2003 and Bhushan et al., 2007). Farmers prefer this technology due to farm labour shortage, rising fuel price, deteriorating soil and environmental health. In this background, it is anticipated that production cost and labour saving conservation agriculture technology, such as zero tillage wheat and tillage specific wheat varieties would generate significant positive livelihood impacts. Information on tillage specific wheat varieties is another major constraint in wheat production. The varieties found suitable for conventional method of wheat cultivation may not be suitable for significance performance under zero tillage condition. Hence, varietal identification for its suitability under specific tillage practices is needed.

Almost $20 \%$ of the total operational energy required is consumed for tillage which is done for sowing any crop. Conventional tillage practices followed by farmers for raising cultivation wheat after puddle rice involve extensive use of machines, labour, waste of time and energy as large number of tractor operations are performed to change the low permeability soil structure created for rice to well aerated structure for wheat. It has also been estimated that on an average $30-35 \%$ of total expenditure of crop production is incurred on tillage and sowing operations. To mitigate these negative effects, resource conservation technologies (RCTs) likes zero tillage, bed planting and laser land levelling saved substantial quantity of irrigation water, reducing the cost of cultivation in terms of land preparation, timely sowing, decreased seed rate, improved water and nutrient-use efficiency, and left indirect effect on mitigating the adverse effect of climate changes (Jat et al., 2014). In general 6-12 tractor operations are performed for growing wheat in different part of the Indo-Gangatic plains depending upon the soil types.

Zero tillage is an extreme form of minimum tillage in which primary tillage is completely avoided and secondary tillage is restricted to seedbed preparation in the row zone only. It is the direct sowing of seed in the field without any disturbance to the soil. Zero tillage planting is a resource- conserving approach, and it helps to control obnoxious weeds, less fuel consumption, better soil structure, texture, shortened field time during tillage operation, increased soil water availability and increased number of Bio-pores, that may facilitate good root growth.

\section{Materials and Methods}

\section{Site of the experiment plot}

The location of Bihar Agricultural College, Sabour is between $25^{\circ} 15^{\prime} 40^{\prime \prime}$ North longitude $87^{\circ} 2$ '55" East Latitude with an elevation of $45.72 \mathrm{~m}$ above the mean sea level in the heart of the vast alluvial Gangetic. The climate of the region is semi-arid, subtropical with hot desiccating summer, cold but frost less winter 
with an average annual rainfall of about 1150 $\mathrm{mm}$ precipitating mainly in between $2^{\text {nd }}$ fortnight of June to last week of October.

\section{Experimental details}

The experimental study was laid out in split plot design and replicated three (3) times. Main plot having two treatments i.e. conventional tillage (CT) and zero tillage (ZT) options and Sub-plots having six treatments i.e. six different wheat genotypes.

Table.A Layout details

\begin{tabular}{|l|l|}
\hline Design & Split plot design \\
\hline Replication & 03 (Three) \\
\hline Treatment (main plot) & 02 \\
\hline Treatments (sub-plot) & 06 \\
\hline Total plot & 03 \\
\hline Plot size (Gross) & $8.0 \mathrm{~m} \mathrm{x} \mathrm{1.8m}$ \\
\hline Net plot size & $7.0 \mathrm{~m} \mathrm{x} \mathrm{1.4m}$ \\
\hline $\begin{array}{l}\text { Bund } \\
\text { treatments }\end{array}$ & $1.0 \mathrm{~m}$ \\
\hline Spacing & $120 \mathrm{~cm}$ apart R to R \\
\hline Fertilizer dose & $\begin{array}{l}150: 60: 40 \\
\left(\mathrm{~N}: \mathrm{P}_{2} \mathrm{O}_{5}: \mathrm{K}_{2} \mathrm{O}\right)\end{array}$ \\
\hline Seed rate & $100 \mathrm{~kg} / \mathrm{ha}$ \\
\hline
\end{tabular}

\section{Genotypes of wheat used for experiment}

The cultivation of all these wheat variety in North Eastern Plain Zone (NEPZ) is mainly recommended for eastern UP, Bihar, Jharkhand and West Bengal, under timely sown-irrigated and high fertility conditions.

The optimum sowing time of these variety is second-third week of November and these respond well up to $150 \mathrm{~kg} \mathrm{~N} / \mathrm{ha}$. The varieties are as follows: BRW $3708\left(\mathrm{~V}_{1}\right)$, CBW 38 $\left(\mathrm{V}_{2}\right)$, DBW $39\left(\mathrm{~V}_{3}\right)$, HD $2967\left(\mathrm{~V}_{4}\right)$, HD 2733 $\left(\mathrm{V}_{5}\right)$ and $\mathrm{K} 0307\left(\mathrm{~V}_{6}\right)$.

\section{Preparation of experimental plot}

The experimental plot was prepared by cross harrowing of the land followed by cross ploughing with cultivator. Each ploughing was followed by planking in order to pulverize the soil, weeds, root stubbles and other crop residues were removed and the levelling of land is an essential component of land preparation, as it ensure uniform availability of water to the plants, and avoid stagnation of water and fertilizers to the crop in the field.

After thorough preparation of the land, the experiment was statistically laid out in the field adopting split plot design with six treatments replicated three times. Each treatment was allocated to individual plot in judicial manners.

\section{Methods of fertilizers application}

Recommended dose of fertilizer i.e. 150:60:40 kg/ha N: $\mathrm{P}_{2} \mathrm{O}_{5}: \mathrm{K}_{2} \mathrm{O}$ was applied to wheat crop. Half dose of nitrogen as urea with full dose of phosphorus $\left(\mathrm{P}_{2} \mathrm{O}_{5}\right)$ as DAP and potash $\left(\mathrm{K}_{2} \mathrm{O}\right)$ as muriate of potash were applied before sowing of seeds in the field as basal application. The remaining each of $25 \%$ doses of nitrogen was applied at jointing and tillering stage.

\section{Sowing and spacing}

The land was thoroughly ploughed and prepared for sowing. Fertilizers were applied as per recommendation (i.e. $75 \mathrm{~kg} \mathrm{~N}+60 \mathrm{~kg}$ $\mathrm{P}_{2} \mathrm{O}_{5}+40 \mathrm{~kg} \mathrm{~K} 2 \mathrm{O} / \mathrm{ha}$ ), at a depth of about 5 $\mathrm{cm}$ below the seed furrow as a basal application and remaining two doses each of $37.5 \mathrm{~kg} \mathrm{~N}$ applied as foliar spray at jointing and tillering stage of wheat crop. Seeds of wheat varieties having satisfactory germination percentage were treated with bavistin@2g/kg of seed before sowing. A 
seed rate of $100 \mathrm{~kg} / \mathrm{ha}$ was maintained along with row spacing of $20 \mathrm{~cm}$ apart using precision plot planter.

\section{Inter-Culture activities and irrigation}

Weeding is done after four days of first irrigation when the field is ready to workable condition in order to provide easy intercultural operations. Inter cultural operation on standing wheat crop was done by the Sharma hoe agricultural implements suitable for eliminating the weeds and pulverization of inter row spaces for better aeration and root penetration, respiration and to provide weed free condition to crop during active growth period.

\section{Harvesting and threshing}

The crop was harvested manually on $22^{\text {th }}$ April, 2017, from the net plot area. After sun drying in open air for three days, the total produce was weighed in bundles. Then the threshing was carried out. Produce of all the plots was threshed separately with threshing machine and grain weight was recorded after cleaning.

\section{Statistical analysis}

A split plot design with 12 treatments and three replications were used for this experimental study. Data were subjected to analysis of variance. The results were interpreted on the basis of ' $F$ ' test (Fisher, 1935) and critical difference (CD) between treatments mean.

Interaction effects were discussed only wherever they were found applicable i.e., significant. Significance among mean was analysed using analysis of variance at $p$ $>0.05$. The experimental data for different characters were subjected to statistical analysis by adopting the methods appropriate to the design (Cochran and Cox, 1963).

\section{Results and Discussion}

\section{Site of the experiment plot}

With regard to the data presented in table no. - 1, the climate of the Bihar Agricultural University, Sabour is tropical to subtropical with slightly semi-arid in nature and is characterized by very hot and dry summer, moderate rainfall and very cold winter.

December and January are usually the coldest months with the mean temperature normally as low as $8.2^{\circ} \mathrm{C}$ whereas; May and June are the hottest months, having the maximum average temperature of $29.6^{\circ} \mathrm{C}$.

Effect of tillage options and wheat genotypes on $\mathrm{N}, \mathrm{P}, \mathrm{K}$, content $(\%)$ in grains

The mean data on $\mathrm{N}, \mathrm{P}, \mathrm{K}$, content (\%) in grains of wheat as influenced by different tillage options and wheat genotypes have been depicted in table no. -2 .

Analyzed data revealed that $\mathrm{N}(1.44 \%), \mathrm{P}$ $(0.46 \%)$, and $\mathrm{K}(0.28 \%)$, content in grains under zero tillage and $\mathrm{N}(1.44 \%), \mathrm{P}(0.45 \%)$, and $\mathrm{K}(0.28 \%)$, content in grains under conventional tillage practices was statistically at par i.e. no significant variation was observed in $\mathrm{N}, \mathrm{P}, \mathrm{K}$, content $(\%)$ in grains of wheat under different tillage options. Among them different wheat genotypes, the genotypes BRW 3708 produced maximum mean $\mathrm{N}(1.53 \%), \mathrm{P}(0.50 \%)$ and $\mathrm{K}(0.31 \%)$ content in grain which was statistically at par with the mean $\mathrm{N}, \mathrm{P}, \mathrm{K}$, content in grains in all the genotypes.

\section{Effect of different tillage options and wheat genotypes on $N, P, K$ content in straw}

The mean data on $\mathrm{N}, \mathrm{P}, \mathrm{K}$, content $(\%)$ in straw of wheat as influenced by different tillage options and wheat genotypes have 
been given in table no. - 2. Analyzed data revealed that the effect due to different tillage practices and different wheat genotypes on $\mathrm{N}$, $\mathrm{P}, \mathrm{K}$ content in straw were recorded statistically non significant.

\section{Effect of different tillage options and wheat genotypes on $\mathrm{N}, \mathrm{P}$, K uptake (kg/ha) by grains}

The pooled data of experimentation on $\mathrm{N}, \mathrm{P}$ and $\mathrm{K}$ uptake by grains of wheat as influenced by different tillage options and wheat genotypes have been presented in table no. 3.

The analysed pooled data on $\mathrm{N}, \mathrm{P}$ and $\mathrm{K}$ uptake by grains reveal that the effect of different tillage options was found to be statistically at par where as different wheat genotypes recorded significant variation in $\mathrm{N}$, $\mathrm{P}$ and $\mathrm{K}$ uptake by grains. Among them different wheat genotypes, the genotypes BRW 3708 recorded maximum mean nitrogen (81.94 kg/ha), phosphorus (16.06 kg/ha), potassium $(19.14 \mathrm{~kg} / \mathrm{ha})$ uptake which was significantly superior to others. Where as the lowest nitrogen $(60.43 \mathrm{~kg} / \mathrm{ha})$, phosphorus $(8.47 \mathrm{~kg} / \mathrm{ha})$, and potassium $(11.42 \mathrm{~kg} / \mathrm{ha})$ uptake was recorded from the wheat genotypes K0307.

Effect of different tillage options and wheat genotypes on $\mathrm{N}, \mathrm{P}, \mathrm{K}$ uptake (kg/ha) by straw

The pooled data of experimentation on $\mathrm{N}, \mathrm{P}$ and $\mathrm{K}$ uptake by straw of wheat as influenced by different tillage options and wheat genotypes have been presented in table no. 3. The analysed pooled data on $\mathrm{N}, \mathrm{P}$ and $\mathrm{K}$ uptake by straw reveal that the effect of different tillage options was found to be statistically at par where as different wheat genotypes recorded significant variation in $\mathrm{N}$, $\mathrm{P}$ and $\mathrm{K}$ uptake by straw.

Among them different wheat genotypes, the genotypes BRW 3708 recorded maximum mean nitrogen $(38.8 \mathrm{~kg} / \mathrm{ha})$, phosphorus $(26.3$ $\mathrm{kg} / \mathrm{ha})$ and potassium $(98.2 \mathrm{~kg} / \mathrm{ha})$ uptake which was significantly superior to others .where as the lowest nitrogen $(26.6 \mathrm{~kg} / \mathrm{ha})$, phosphorus $(17.9 \mathrm{~kg} / \mathrm{ha})$ and potassium $(78.8$ $\mathrm{kg} / \mathrm{ha}$ ) uptake was recorded from the wheat genotypes K 0307.

Conventional tillage recorded higher uptake of nitrogen, and potassium by grain and straw than zero tillage system, whereas zero tillage recorded slightly higher uptake of phosphorus than conventional tillage system. This could be possible due more number of soil micro flora and fauna available in zero tillage condition than conventional tillage practices.

These entire factors could be ascribed to the vegetative and reproductive growth responsible for producing higher grain and straw yield under both tillage system are statistically at par.

The higher mineralization rate was also responsible for more availability of nutrient which results in higher uptake of nutrients.

Among wheat genotypes, BRW 3708 recorded the highest NPK uptake by grain and straw the uptake of NPK in grain and straw follows the order BRW $3708>$ CBW $38>$ DBW 39 > HD 2967 > HD 2733 > K 0307 , similar findings go in-line with Patel et al., (1999) and Kumar and Singh (2003). 
Table.1 Weekly weather variations during crop season 2016 - 17

\begin{tabular}{|c|c|c|c|c|c|c|c|}
\hline \multirow[t]{2}{*}{$\begin{array}{l}\text { Standard } \\
\text { weeks }\end{array}$} & \multirow[t]{2}{*}{ Date } & \multicolumn{2}{|c|}{$\begin{array}{c}\text { Temperature } \\
\left({ }^{0} \mathrm{C}\right)\end{array}$} & \multicolumn{2}{|c|}{ RH (\%) } & \multirow{2}{*}{$\begin{array}{c}\text { Rainfall } \\
\mathrm{mm} \\
\end{array}$} & \multirow{2}{*}{$\begin{array}{c}\text { Wind } \\
\text { Speed } \\
\mathrm{km} / \mathrm{hr}\end{array}$} \\
\hline & & Max. & Min & Max & Min & & \\
\hline 42 & 21-27 Oct & 30.9 & 19.5 & 89.8 & 62.1 & 0.0 & 1.9 \\
\hline 43 & 28 Oct-03 Nov & 30.5 & 18.8 & 89.7 & 64.8 & 0.0 & 2.2 \\
\hline 44 & 04-10 Nov & 30.6 & 16.1 & 86.8 & 60.7 & 0.0 & 2.2 \\
\hline 45 & 11-17 Nov & 29.2 & 13.7 & 92.0 & 50.4 & 0.0 & 2.3 \\
\hline 46 & 18-24 Nov & 27.8 & 11.8 & 92.0 & 47.7 & 0.0 & 2.0 \\
\hline 47 & 25 Nov-01 Dec & 27.0 & 12.6 & 91.5 & 62.1 & 0.0 & 1.2 \\
\hline 48 & 02-08 Dec & 24.4 & 11.6 & 95.7 & 72.4 & 0.0 & 3.4 \\
\hline 49 & 09-15 Dec & 18.7 & 7.9 & 97.2 & 75.7 & 0.0 & 5.5 \\
\hline 50 & 16-22 Dec & 23.2 & 8.1 & 94.7 & 59.2 & 0.0 & 2.9 \\
\hline 51 & 23-29 Dec & 23.8 & 10.7 & 95.5 & 70.0 & 0.0 & 3.2 \\
\hline 01 & 01-07 Jan & 21.1 & 8.6 & 98.2 & 76.0 & 0.0 & 4.0 \\
\hline 02 & 08-14 Jan & 21.3 & 7.9 & 95.5 & 60.5 & 0.0 & 2.9 \\
\hline $\mathbf{0 3}$ & 15-21 Jan & 22.6 & 6.0 & 93.2 & 48.2 & 0.0 & 3.2 \\
\hline 04 & 22-28 Jan & 25.2 & 8.2 & 91.4 & 58.5 & 12.4 & 3.4 \\
\hline 05 & 29Jan-04 Feb & 22.1 & 7.8 & 97.7 & 63.1 & 0.0 & 4.6 \\
\hline 06 & 05-09 Feb & 26.0 & 7.6 & 89.4 & 50.5 & 0.0 & 3.8 \\
\hline 07 & $12-16 \mathrm{Feb}$ & 26.7 & 9.4 & 87.5 & 46 & 0.0 & 1.4 \\
\hline 08 & $19-25 \mathrm{Feb}$ & 28.4 & 11.1 & 87.0 & 44.2 & 0.0 & 2.5 \\
\hline 09 & 26Feb-04 Mar & 29.1 & 13.4 & 82.8 & 36 & 0.0 & 3.0 \\
\hline 10 & 05-11 Mar & 28.9 & 12.9 & 84.5 & 53.2 & 3.2 & 3.6 \\
\hline 11 & 12-18 Mar & 28.4 & 11.9 & 83.0 & 49.5 & 0.6 & 4.0 \\
\hline 12 & 19-25 Mar & 30.3 & 16.4 & 87.5 & 56.1 & 5.9 & 4.3 \\
\hline 13 & 26Mar-01 Apr & 31.5 & 21.5 & 94.2 & 67.4 & 6.8 & 5.7 \\
\hline 14 & 02-08 Apr & 32.9 & 21.7 & 92.5 & 64.2 & 0.0 & 8.0 \\
\hline 15 & 09-15 Apr & 36.8 & 19.8 & 64.0 & 34.4 & 0.0 & 6.1 \\
\hline 16 & 16-22 Apr & 32.0 & 21.9 & 88.2 & 59.7 & 0.0 & 7.8 \\
\hline 17 & 23-29 Apr & 36.9 & 22.4 & 70.9 & 42.3 & 5.8 & 5.7 \\
\hline 18 & 30Apr-06 May & 35.7 & 22.7 & 79.9 & 49.0 & 3.8 & 4.4 \\
\hline
\end{tabular}


Table.2 Effect of different tillage options and wheat genotypes on nutrient content of wheat grain and straw

\begin{tabular}{|l|c|c|c|c|c|c|}
\hline & \multicolumn{3}{|c|}{ Nutrient Content in Grain, \% } & \multicolumn{3}{c|}{ Nutrient Content in Straw, \% } \\
\hline Treatment & N content & P content & K content & N content & P content & K content \\
\hline Main plot & & & & & & \\
\hline CT & 1.44 & 0.45 & 0.28 & 0.46 & 0.05 & 1.28 \\
\hline ZT & 1.44 & 0.46 & 0.28 & 0.48 & 0.05 & 1.29 \\
\hline CD (P=0.05) & NS & NS & NS & NS & NS & NS \\
\hline Sub plot & & & & & & \\
\hline BRW 3708 & 1.53 & 0.50 & 0.31 & 0.49 & 0.05 & 1.32 \\
\hline CBW 38 & 1.49 & 0.46 & 0.29 & 0.49 & 0.05 & 1.30 \\
\hline DBW 39 & 1.44 & 0.45 & 0.29 & 0.47 & 0.05 & 1.30 \\
\hline HD 2967 & 1.40 & 0.44 & 0.28 & 0.46 & 0.05 & 1.28 \\
\hline HD 2733 & 1.41 & 0.43 & 0.25 & 0.45 & 0.05 & 1.28 \\
\hline K 0307 & 1.39 & 0.42 & 0.25 & 0.44 & 0.04 & 1.22 \\
\hline CD (P=0.05) & NS & NS & NS & NS & NS & NS \\
\hline
\end{tabular}

$\mathrm{CT}=$ Conventional tillage; $\mathrm{ZT}=$ Zero tillage

Table.3 Effect of different tillage options and wheat genotypes on nutrient uptake of wheat grain and straw

\begin{tabular}{|l|c|c|c|c|c|c|}
\hline & \multicolumn{4}{|c|}{ Nutrient Uptake in Grain, kg/ha } & \multicolumn{3}{c|}{ Nutrient Uptake in Straw, kg/ha } \\
\hline Treatment & N uptake & P uptake & K uptake & N uptake & P uptake & K uptake \\
\hline Main plot & & & & & & \\
\hline CT & 71.18 & 13.18 & 16.57 & 31.78 & 21.9 & 89.39 \\
\hline ZT & 69.94 & 13.49 & 16.25 & 32.9 & 22.8 & 89.51 \\
\hline CD (P=0.05) & NS & NS & NS & NS & NS & NS \\
\hline Sub plot & & & & & & \\
\hline BRW 3708 & 81.94 & 16.06 & 19.14 & 38.8 & 26.3 & 98.2 \\
\hline CBW 38 & 73.95 & 14.94 & 18.03 & 35.0 & 23.7 & 93.3 \\
\hline DBW 39 & 71.74 & 14.51 & 18.03 & 34.1 & 23.2 & 93.3 \\
\hline HD 2967 & 69.22 & 14.26 & 16.95 & 29.2 & 22.0 & 88.7 \\
\hline HD 2733 & 66.09 & 11.77 & 14.88 & 30.4 & 21.1 & 84.5 \\
\hline K 0307 & 60.43 & 8.47 & 11.42 & 26.6 & 17.9 & 78.8 \\
\hline CD (P=0.05) & 4.0 & 0.80 & 0.90 & 1.7 & 1.0 & 4.4 \\
\hline
\end{tabular}

$\mathrm{CT}=$ Conventional tillage; $\mathrm{ZT}=$ Zero tillage 
Int.J.Curr.Microbiol.App.Sci (2020) 9(6): 3737-3745

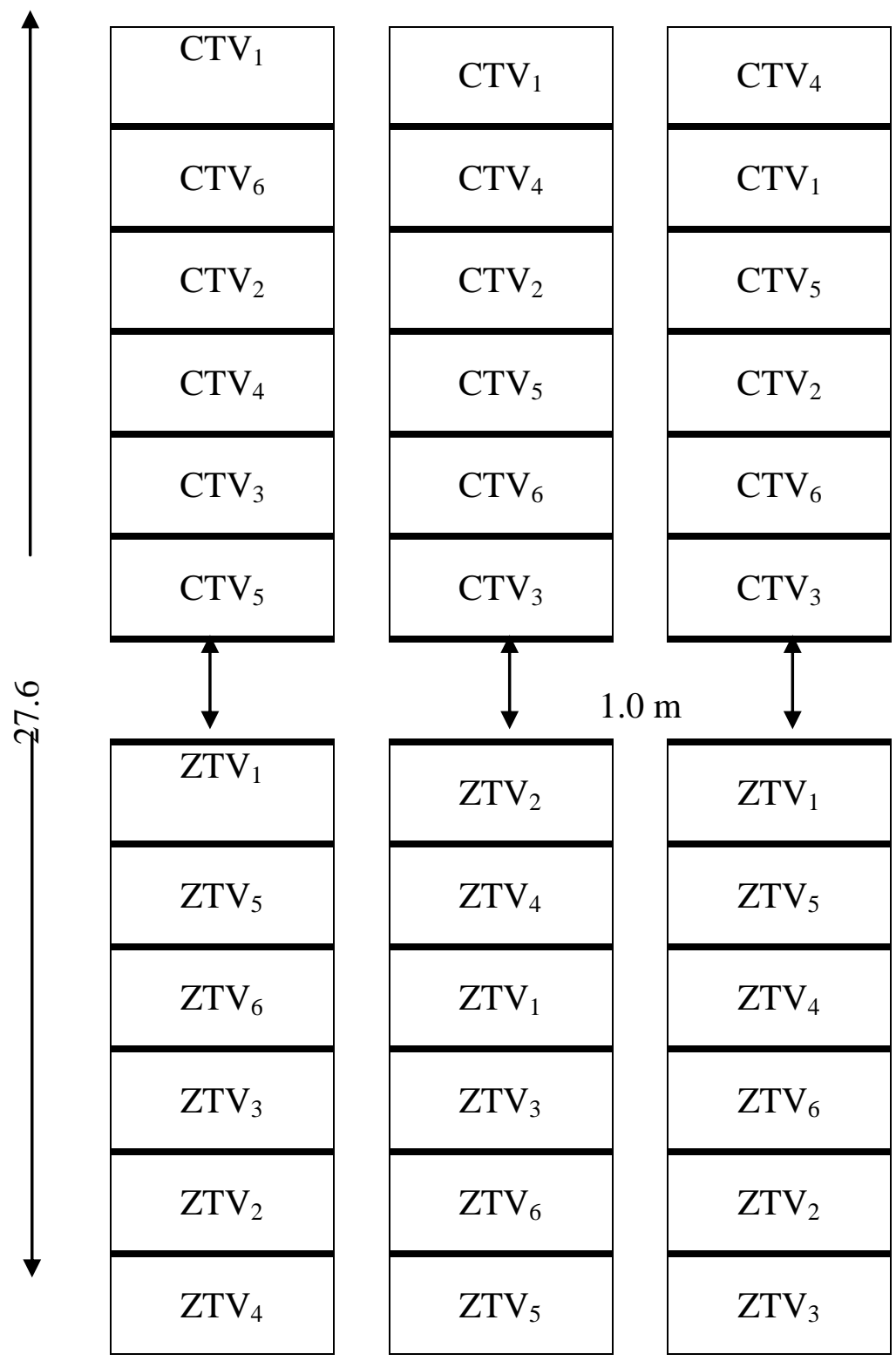

Design: Split-Plot

Replication: Three (03)

Plot Size:

Gross- $1.8 \mathrm{~m} \times 8.0 \mathrm{~m}$

Net- $1.4 \mathrm{~m} \times 7.0 \mathrm{~m}$

Space between Replication; $1.0 \mathrm{~m}$

Space between two sub plots-. $05 \mathrm{~m}$

Treatments:

Main-Plots (Tillage options)

CT- Conventional Tillage

ZT-Zero Tillage

Sub-Plots (Wheat Genotypes)

V $^{-}$BRW3708; $\mathrm{V}_{2^{-}}$CBW38; V $3^{-}$DBW39; $\mathrm{V}_{4}-\mathrm{HD} 2967 ; \mathrm{V}_{5^{-}}$HD2733; $\mathrm{V}_{6^{-}} \mathrm{K} 0307$ (V - different variety).

Fig.1 Layout plan of the field experiment 
As discussed above, the following inference could be drawn. Among the different genotypes taken for study in the experiment, BRW 3708 recorded the highest NPK uptake by grains and straw which follows the order BRW $3708>$ CBW $38>$ DBW $39>$ HD 2967 $>$ HD $2733>$ K 0307.

\section{References}

Ali MA, Ali M, Sattar M, Ali L (2010) Sowing date effect on yield of different wheat varieties. J. Agric. Res. 48(2): 157-162.

Bhushan L, Ladha JK, Gupta RK, Singh S, Tirol-Padre A, Saharawat YS, Gathala M, Pathak H (2007) Saving of water and labor in a rice-wheat system with no-tillage and direct seeding technologies. Agronomy Journal. 99(5): 1288-1296.

Cochran WG, Cox GM (1963) Experimental designs. New Delhi, Asia publishing house. 611.

Gupta R, Seth A (2007) A review of resource conserving technologies for sustainable management of the rice-wheat cropping systems of the Indo-Gangetic plains (IGP). Crop protection. 26(3): 436-447.

Irfaq M, Mumhammad T, Amin M, Jabbar A (2005) Performance of yield and other agronomic characteristics of four wheat genotypes under natural heat stress. International Journal of Botany. 1(2) :124-127.

Jat RK, Sapkota TB, Singh RG, Jat ML, Kumar M, Gupta RK (2014) Seven years of conservation agriculture in a rice-wheat rotation of Eastern Gangetic Plains of South Asia: Yield trends and economic profitability. Field Crop Research. 164: 199-210.

Kumar M, Singh M (2003) Effect of nitrogen and phosphorus levels on yield and nutrient uptake in maize (Zea mays L.) under rainfed condition of Nagaland. CROP RESEARCH-HISAR 25(1): 4649.

Malik RK, Yadav A, Singh S, Sardana PK, Gill G, Hobbs PR, Bellinder R (2003) Herbicide resistance management and introduction of zero tillage in wheat in India. Proceedings of Weed Science Society of America. 43-55.

Patel SR, Thakur DS, Lal N (1999) Yield and nutrient uptake of wheat (Triticum aestivum) varieties under different sowing dates. Indian Journal of Agronomy. 44(4): 733-737.

Sharma RC (1992) Duration of the vegetative and reproductive period in relation to yield performance of spring wheat. European Journal of Agronomy. 1: 133137.

\section{How to cite this article:}

Mamta, Mizanul Haque, Nitu Kumari, Manish Kumar, Ashwini Kumar and Pooja Kumari. 2020. Effect of Zero Tillage and Analysing the Performance of Six Different Cultivars of Wheat (Triticum aestivum L.). Int.J.Curr.Microbiol.App.Sci. 9(06): 3737-3745. doi: https://doi.org/10.20546/ijcmas.2020.906.441 